Original Article

\title{
IN VITRO EVALUATION OF ANTIBACTERIAL PROPERTY OF CATHARANTHUS ROSEUS (LINN.) G. DON. VAR. "ROSEA" AND “ALBA"
}

\author{
AMRESH KUMAR YADAV*, SANJEEV KUMAR AMBASTA, SURENDRA KUMAR PRASAD, M. P. TRIVEDI
}

Department of Botany, Patna University, Patna 800005, Bihar, India

Email: amresh27@gmail.com

Received: 27 Jan 2018 Revised and Accepted: 22 Mar 2018

\begin{abstract}
Objective: To evaluate the antibacterial property of crude, aqueous and organic solvent extract from leaf, stem and root parts of two different var. of Catharanthus roseus (i.e. "rosea" and "alba") under in vitro conditions on various human pathogenic bacteria.

Methods: Antibacterial activity of crude (fresh), aqueous, ethanolic, methanolic and equimolar (1:1) mixture of ethanolic dried leaf extract of variety "rosea" and "alba" was evaluated against various pathogenic bacteria viz. Bacillus subtilis, Escherichia coli and Staphylococcus aureus by disk diffusion method under in vitro conditions.

Results: Gram-positive bacteria were found to be more susceptible than Gram-negative. Dried extracts of root, stem and leaf of $C$. roseus var. "rosea" and "alba" plants showed maximum antibacterial potency against all the test microorganisms. The equimolar mixture of ethanolic dried leaf extracts of species "rosea" and "alba" exhibited the maximum zone of inhibition against B. subtilis, E. coli and S. aureus as compare to extract prepared from individual parts. The findings of the ethanolic mixture of dried leaves of the two varieties on the tested bactera confirm that the effect is potentiating which may be synergistic or additive.
\end{abstract}

Conclusion: From the findings, it could be inferred that $C$. roseus var. "rosea" and "alba" could be efficiently used in the development of new lifesaving drugs against bacterial pathogens.

Keywords: Catharanthus roseus, Pathogenic bacteria (B. subtilis, E. coli, S. aureus), In vitro, Zone of Inhibition, Drug resistance

(c) 2018 The Authors. Published by Innovare Academic Sciences Pvt Ltd. This is an open access article under the CC BY license (http://creativecommons.org/licenses/by/4.0/] DOI: http://dx.doi.org/10.22159/ijpps.2018v10i5.24977

\section{INTRODUCTION}

The increasing resistance of microorganisms against the existing drugs is emerging as a global threat in therapy [1]. Irregular and inappropriate use of synthetic drugs against bacterial, viral and fungal pathogens develop resistance against antibiotics due to the production of some chemical substances which block the action of antimicrobial drugs along with the change in target sites and their ability to penetrate across the cell wall. Such kinds of drugs may also cause oxidative stress, production of radicals, damages of nucleic acids, proteins, lipids, cells, organs, and organ system. It has been estimated that about $80 \%$ of the world population depends on plantderived products. World Health Organization (WHO) depicted that $28 \%$ of plant-based products and their derivatives are available as the source of drugs [2]. Antimicrobial drugs of plant origin are safe, no side effects, host-specific, and no drug-drug interaction has been reported. Drugs of plant origin have an added advantage of being highly effective and offer broad-spectrum activity, hold a wide range of bioactive compounds, which can be used to treat cancers and a wide range of contagious diseases [3]. Bacterial resistance to antibiotics urges resurgence to search for new classes of potentially useful and biologically active chemicals of plant origin to develop and design new drugs, as they provide unique elements of molecular diversity and biological functionality, which are indispensable for novel drug discovery Antimicrobial drugs of plant origin are safe, no side effects, host-specific, and no drug-drug interaction has been reported. Hence, present scenario necessitates a continuing search for new classes of antimicrobial and biologically active compounds derived from medically important flora. [4-8]. Drugs of plant origin have an added advantage of being highly effective and offer broadspectrum activity, hold a wide range of bioactive compounds, which can be used to treat cancers and a wide range of contagious diseases [9]. Indigenous systems of plant-derived medicine have strong roots as it provides both concepts of therapy and therapeutic principles to complement modern medicine, especially in the management of lifestyle and communicable diseases. Medicinal plant products have proved to be prolonging longevity and good health by minimizing the adverse effect of various chemicals [10]. Such plants are widely distributed in nature, but unfortunately, the small number of them has been explored for the treatment of diseases caused by microorganisms.

India is blessed with richest, unexplored medicinal biodiversity and also has an ancient tradition of using herbs to cure various diseases [11]. Catharanthus roseus L. (G). Don, family-Apocynaceae is a perennial herb, $25-30 \mathrm{~cm}$ tall with dark glossy green leaves. All the plant parts, i.e. root, stem, leaves, and flowers produce several phytoactive compounds viz. Flavonoids, steroids, terpenoids, tannin, phenolics, anthocyanins, fatty acids, proteins, phytohormones, and enzymes [12-14]. Traditionally, the two cultivars of Catharanthus have been used in folk medicine to take care of diabetes, high blood pressure, diarrhea and several diseases caused by microorganism [1517]. Current scientific findings provide evidence for the anticancerous and antibacterial properties of $C$. roseus plants $[18,19]$.

Vinblastin and vincristine (Spindle poison) are known as the principal bio-active compound synthesized from the pink cultivar, which is used to treat acute leukemia, Hodgkin's disease, rhabdomyosarcomas, neuroblastoma and other forms of lymphomas [20-22]. The emerging trend of herbal origin drugs at national and international platform compelled the investigators to evaluate the antibacterial property of crude, aqueous and organic solvent extracts from different plant parts of two cultivars C. roseus var. "rosea" and "alba" under in vitro conditions.

\section{MATERIALS AND METHODS}

\section{Collection and preparation of plant materials}

Plants of Catharanthus roseus var. "rosea" (pink flower) and "alba" (white flower) were collected in April and May 2017 from the research garden of Department of Botany, Patna University, Patna. Fresh disease free healthy plants were collected, identified and authenticated by Haines flora [23]. Root, stem, and leaves were 
separated, washed to remove contaminants under running tap water followed by washing with Double distilled water (DDW) for 3 to 4 times, excess water removed and dried under semi-shade conditions.

\section{Preparation of extracts}

Plant parts (root, stem, and leaf) of both the cultivars (Pink and White) were used to prepare different extracts i.e. [i] Crude [ii] Aqueous and [iii] Organic solvents.

\section{Crude extract}

$100 \mathrm{gm}$ each of fresh root, stem and green leaves were separately ground, filtered and centrifuged at 3000rpm (10 min), supernatant re-filtered and kept in a sterilized glass bottle and kept at $4{ }^{\circ} \mathrm{C}$ in the outer cabinet of the refrigerator.

\section{Aqueous extract}

100 gm each dried plant parts were macerated separately, mixed in $100 \mathrm{ml}$ of DDW, kept overnight at room temperature, twice filtered, stored in sterilized storage bottle at $4{ }^{\circ} \mathrm{C}$.

\section{Organic solvent extract}

$100 \mathrm{gm}$ powder of plant parts were soaked separately in $100 \mathrm{ml}$ of methanol and ethanol for $72 \mathrm{~h}$ at room temperature, filtered, concentrated up to $5 \mathrm{ml}$, cooled, refiltered and stored at $4{ }^{\circ} \mathrm{C}$.

\section{Isolation of test organisms}

Pure bacterial colonies were isolated from two different sources i.e. Soil and Sewage, collected from the campus of Magadh Mahila College, P. U and Collectorate Ghat, Patna. The soil sample was diluted up to 10 ${ }^{6}$ dilution, and spread on NA plates for $24 \mathrm{~h}$ and incubated at $37{ }^{\circ} \mathrm{C}$ in an inverted position. Bacterial colonies appearing on the plates were purified and repeatedly subcultured by streak plate technique. The strain was isolated and preserved at $4{ }^{\circ} \mathrm{C}$ in NA medium.

\section{Characterization of bacterial isolates}

Pure bacterial colonies were characterized by phenotypic observation of the basic colony morphology, Gram's staining, and Biochemical analysis. Identification and authentication of isolates were done by Bergey's Manual of Systemic Bacteriology [24].

\section{Assay for antibacterial activities}

The antibacterial activities were evaluated by Disc diffusion technique. The Muller Hinton Agar (MHA) were autoclaved, cooled to $40{ }^{\circ} \mathrm{C}$ and poured $(20 \mathrm{ml})$ in Petri dishes, kept at room temperature for solidification and stored at $4{ }^{\circ} \mathrm{C}$. Pure bacterial isolates of B. subtilis, E. coli, and S. aureus were spread over the agar plates with the sterile cotton swab and incubated overnight at $37^{\circ} \mathrm{C}$.

\section{Preparation of antibiotic discs}

Several discs ( $5 \mathrm{~mm}$ ) were punched form Whatman filter paper No.1 were soaked in crude, aqueous, ethanolic, methanolic and equimolar (1:1) mixture of dried ethanolic leaf extract of variety "rosea" and "alba", were placed on MHA plates and inoculated at $37^{\circ} \mathrm{C}$. After $24 \mathrm{~h}$ of incubation, the diameter of the inhibition zone was measured. Discs of crude extract were taken as control and all the experiments were done in triplicate.

\section{RESULTS}

The experimental results reveal that almost all the parts of $C$. roseus var. "rosea" and "alba" shows antibacterial property against all test organisms, i.e. B. subtilis, E. coli, and S. aureus (table 1). Aqueous, ethanolic and methanolic extracts prepared from the dried powder of the different plant parts, exhibited better antimicrobial activity than crude extract. Ethanolic leaf extracts of both the varieties of Catharanthus exhibit maximum $(17.0 \pm 0.55 \mathrm{~mm})$ and $(17.0 \pm 0.50 \mathrm{~mm})$ zone of inhibition against $S$. aureus followed by $B$. subtilis and E. coli. While minimum $(3.5 \pm 0.50 \mathrm{~mm})$ and $(4.5 \pm 0.72 \mathrm{~mm})$ zone of inhibition was observed by the crude extract of "rosea" and "alba" respectively against $S$. aureus. No results exhibited by aqueous extract by both cultivars. Maximum zone of inhibition was observed in the ethanolic stem extract in "rosea" against $E$. coli followed by $S$. aureus and B. subtilis while almost comparable inhibition was seen in $B$. subtilis and $S$. aureus and minimum against $E$. coli when treated with "alba" ethanolic stem extract. Moreover, the Maximum zone of inhibition was observed by methanolic stem extract of both the varieties exhibited highest antibacterial property against $B$. subtilis followed by $S$. aureus and E. coli. While crude and aqueous extract show minimum inhibitory response with respect to ethanolic and methanolic extract. The ethanolic root extract of "rosea" exhibited maximum (18.5 \pm 0.50$)$ and minimum (11.0 \pm 0.50$)$ inhibition in B. subtilis and E. coli respectively. While "alba" was most effective $(19.6 \pm 0.50)$ against $S$. aureus additionally $E$. coli followed by B. subtilis. While the methanolic extract of "rosea" and "alba" exhibit minimum and almost comparable effect against all test organisms. The minimum inhibitory response was exhibited by both the crude and aqueous extract of leaf, stem, and root respectively.

Surprisingly, an ethanolic equimolar mixture of "rosea" and "alba" dried leaf extract exhibited a maximum zone of inhibition i.e. (25.5 \pm 0.60$),(22.0 \pm 0.40)$ and $(22.5 \pm 0.50)$ against B. subtilis, E. coli and $S$. aureus respectively.

Table 1: Antibacterial activity in different solvents of $C$. roseus var. "rosea" and "alba"

\begin{tabular}{|c|c|c|c|c|}
\hline \multirow{2}{*}{$\begin{array}{l}\text { Plants } \\
\text { part }\end{array}$} & \multirow{2}{*}{$\begin{array}{l}\text { Extract of } C \text {. roseus } \\
\operatorname{rosea}(R) / \operatorname{alba}(A)\end{array}$} & \multicolumn{3}{|c|}{ Test organism and Zone of inhibition $(\mathrm{mm} \pm \mathrm{SE})$} \\
\hline & & B. subtilis (R/A) & E. $\operatorname{coli}(\mathrm{R} / \mathrm{A})$ & S. aureus(R/A) \\
\hline \multirow[t]{4}{*}{ Leaf } & Crude & $+/+$ & $+/+$ & $3.5 \pm 0.50 / 4.5 \pm 0.72$ \\
\hline & Aqueous & $-/-$ & $-/-$ & $-/-$ \\
\hline & Ethanol & $11.5 \pm 0.45 / 11.5 \pm 0.60$ & $10.2 \pm 0.60 / 14.2 \pm 0.65$ & $17.0 \pm 0.55 / 17.0 \pm 0.50$ \\
\hline & Methanol & $14.5 \pm 0.50 / 17.5 \pm 0.50$ & $12.5 \pm 0.50 / 11.5 \pm 0.45$ & $16.2 \pm 0.40 / 12.5 \pm 0.50$ \\
\hline \multirow[t]{4}{*}{ Stem } & Crude & $4.0 \pm 0.65 /+$ & $+/+$ & $-/ 5.0 \pm 0.65$ \\
\hline & Aqueous & $-/-$ & $-/-$ & $-/-$ \\
\hline & Ethanol & $15.0 \pm 0.65 / 18.0 \pm 0.50$ & $18.0 \pm 0.45 / 14.0 \pm 0.50$ & $15.5 \pm 0.50 / 18.0 \pm 0.50$ \\
\hline & Methanol & $19.5 \pm 0.65 / 16.5 \pm 0.75$ & $12.0 \pm 0.50 / 12.0 \pm 0.45$ & $14.0 \pm 0.50 / 14.0 \pm 0.45$ \\
\hline \multirow[t]{4}{*}{ Root } & Crude & $-/-$ & $-/ 4.5 \pm 0.50$ & $+/+$ \\
\hline & Aqueous & $-/-$ & $-/-$ & $-/-$ \\
\hline & Ethanol & $18.5 \pm 0.50 / 14.0 \pm 0.60$ & $11.0 \pm 0.50 / 18.1 \pm 0.55$ & $16.6 \pm 0.50 / 19.6 \pm 0.50$ \\
\hline & Methanol & $10.0 \pm 0.45 / 13.0 \pm 0.40$ & $12.2 \pm 0.65 / 12.0 \pm 0.60$ & $14.5 \pm 0.50 / 12.5 \pm 0.50$ \\
\hline \multirow[t]{2}{*}{ Leaf } & Ethanol (Mix) & $25.5 \pm 0.65$ & $22.0 \pm 0.40$ & $22.5 \pm 0.50$ \\
\hline & $\mathrm{R} / \mathrm{A}$ & & & \\
\hline
\end{tabular}

Experiments were carried in triplicate, and each data is the mean value $\pm \mathrm{SD} . \mathrm{mm}=$ millimeter; $\mathrm{S}$ E = Standard error; $(+/-=$ present $/ \mathrm{absent}) ; \mathrm{R} / \mathrm{A}=$ rosea $/$ alba

\section{DISCUSSION}

Herbal medicines are the valuable and readily available resources for complementary and supplementary human health care system.
The natural flora holds varieties of species with medicinally useful products are yet unexplored. WHO (2002) predicted that increasing resistance of microbes against existing drugs throws the challenge to find alternative therapy which necessitates the search for newer 
pharmacologically active ingredients of plant origin. They recognized several important medicinal plants used in the traditional medical system, provided strategies, guidelines, and standard for plant products. Herbs are deeply rooted in our culture and traditions as India is the cradle of biodiversity. The significant number of medicinal plants has been screened pharmacologically for traditional uses against the antibiotic-resistant human and plant pathogens; still, a large number of floras need to be explored for innumerable phytoactive compounds.

Three bacteria viz. B. Subtilis, E. coli and S. aureus were tested for the antibacterial properties of $C$. roseus var. "rosea" and "alba". All the three bacteria used as test organisms in this study, are pathogenic causing several dreaded diseases in human. B. Subtilis is a Gram+, nonpathogenic bacterium, although it secretes an extracellular toxin called subtilisin, which causes food poisoning, allergic reactions, hemolysis, endocarditis and septicemia in drug abused cancerous patients in human. E. coli is a Gram, motile, nonspore bearing enterobacteria causing gastrointestinal disease and cholera, leading to fatal complications such as hemolytic uremic syndrome and thrombocytopenia [25-26]. The other bacteria, S. aureus are Gram; pathogenic, coccid normally present on the skin, urogenital and mucosal respiratory tracts of mammals. It causes various lifethreatening diseases like endocarditis, pneumonia, toxic shock syndrome, and Kawasaki disease [27].

In the present investigation, crude, aqueous, ethanolic and methanolic extracts from leaf, stem and root of $C$. roseus var. "rosea" and "alba" were evaluated for their antimicrobial activities using disc diffusion technique. The findings are discussed under the premise that in reality, no antimicrobial substance inhibits the growth of all the microbes due to variation in the spectrum of activity. So it is desirable to evaluate phytochemicals from different parts to screen the most effective [28]. Almost all parts of "rosea" and "alba" plants showed antibacterial activity in fresh as well as in shade dried condition, but more pronounced in the later phase (table 1). Similar results were reported in C. roseus when extracts were prepared from dried plant parts [29]. The ethanolic and methanolic leaf extracts of both the varieties showed the maximum zone of inhibition followed by root and stem. Organic extracts are inhibitory than aqueous and crude extracts had been remarked by [29] and the present findings are in uniformity with their observations. Leaf ethanolic extracts of "rosea" and "alba" exhibited $(10.2 \pm 0.60-17.0 \pm 0.55 \mathrm{~mm})$ and $(11.5 \pm 0.60-17.0 \pm 0.50 \mathrm{~mm})$ zone of inhibition respectively, which is in conformity with the findings of researcher [30]. Ethanolic leaf extracts of both the varieties showed the maximum zone of inhibition against $S$. aureus (table 1). Similar results were also experimentally proved against Salmonella typhi when treated with $C$. roseus ethanolic leaf extract by disc diffusion method. Results confirmed that ethanolic extract contains some unique phytochemical constituents which are absent in the methanolic extract. Methanolic extracts of both the varieties exhibited minimum antibacterial activity on $E$. coli which is a Gram bacterium, a finding supported by researchers [31]. Gram+bacteria are more susceptible than Gramwhich is probably due to the chemical composition and the structure of the cell walls. The outer membrane of Gram-bacteria acts as a barrier for the entry of antibiotics and the lysozyme present in the periplasmic space digests the foreign molecules. This mechanism makes bacteria resistant to antibiotics. During this investigation, only $B$. subtilis is $\mathrm{Gram}^{+}$which is more susceptible to both the varieties of $C$. roseus as compared to E. coli and $S$. aureus which are gram-(table 1). The ethanolic leaf mixture extract of "rosea" and "alba" were highly effective in inhibiting the growth of all the three test organisms but most effective on B. subtilis (table 1). The antibacterial activity of the mixture may be due to the synergistic effect of "rosea" and "alba" leaves. Synergistic effects have been reported by several workers in different microbes. The findings of the ethanolic equimolar mixture also proved that its contents had more potential to reduce the growth and killing the bacteria by inhibiting the synthesis of DNA, RNA, cell wall and proteins. Extract with high potency brings about the breaking of peptidoglycan chain of bacterial cell wall and transpeptidase which catalyzes the cross-linking of peptidoglycan in the cell wall (WHO 2014). It has been proved that the narrow spectrum antibiotics combined with other antibiotics become part of the broad spectrum therapy and the present findings of the ethanolic mixture on the tested bacterium confirm that the effect may be potentiating or synergistic or additive. This study confirms the use of organic solvents in the preparation of plant extract as compared to aqueous extracts. The polarity of antibacterial compounds makes more readily extracted by organic solvents, and using organic solvents does not negatively affect their bioactivity against bacterial species. This data showed that some antimicrobial substances could only be extracted by organic solvents. Thus, organic solvents are clearly better solvents for antimicrobial activity than the crude and aqueous extracts [32,33].

\section{CONCLUSION}

Several species of Apocynaceae have been used as main ingredients in traditional medicine. From the present study, it could be inferred that C. roseus varieties "rosea" and "alba" could be efficiently used in the development of new life-saving drugs. As present findings that the organic solvent extract of $C$. roseus possesses high antimicrobial potential activity against the test organisms rather than the aqueous and crude extract. It also validates the use of these genera in an ancient medicinal system. The extract could be used in the formulation of new drugs to treat various types of infectious disease caused by pathogens. Further evaluation is needed to identify and confirm the particular compounds to be used in drugs as main ingredients along with pharmacological evaluation. The present study supports longterm use of both the varieties of $C$. roseus as folk medicine due to their natural origin non-toxic effect and high antibacterial principle.

\section{ACKNOWLEDGEMENT}

We are thankful to the Head, Department of Botany, Patna University, Patna, Bihar, India for providing laboratory facilities and to Dr. (Mrs.) C. Prabha, Associate Professor, Botany for constant guidance, encouragement and technical support.

\section{AUTHORS CONTRIBUTIONS}

These authors equally contributed to research work

\section{CONFLICT OF INTERESTS}

We have no conflict of interest

\section{REFERENCES}

1. Harbottle H, Thakur S, Zhao S, White DG. Genetics of antimicrobial resistance. Anim Biotechnol 2006;17:111-24.

2. Newman DJ, Cragg GM, Snader KM. Natural products as a source of new drug over the period 1981-2002. J Nat Prod 2003;6:1022-37.

3. Ambasta SK, Yadav AK, Sinha UK. Evaluation of anticlastogenic potential of Cinnamomum cassia bark extract against arsenic genotoxicity by using micronucleus assay in Mus musculus.

4. S Amrita, D Praveen. Screening of phytochemical and antimicrobial potential of the extract Vetiver zizanoides and Phragmites karka against clinical isolates. Int J Appl Pharm 2015;7:22-4

5. Coates A, Hu Y, Bax R, Page C. The future challenges facing the development of new antimicrobial drugs. Nat Rev Drug Discovery 2002;1:895-910.

6. Nisbet LJ, Moore M. Wild natural products remains an important source of drug research for the future. Curr Opin Biotechnol 1997;8:708-12.

7. Braga LC, Leite AAM, Xavier KGS. Synergic interaction between Pomegranate extracts and antibiotics against Staphylococcus aureus. Can J Microbiol 2005;51:541-7.

8. Das S, Borah M, Ahmed S. Antibacterial activity of the ethanolic extract of leaves of Citrus maximum (Burm.) merr. on Escherichia coli and Pseudomonas aeruginosa. Asian J Pharm Clin Res 2017;6:136-9.

9. Ambasta SK, Yadav AK, Sinha UK. Evaluation of anticlastogenic potential of Cinnamomum cassia bark extract against arsenic genotoxicity by using micronucleus assay in Mus musculus caudal erythrocytes. Asian J Pharm Clin Res 2017;10:150-2.

10. Nair R, Chanda S. Activity of some medicinal plants against certain pathogenic bacterial strains. Indian J Pharmacol 2006;38:142-4.

11. Walsh SE, Maillard JY, Russel AD. Activity and mechanism of action of selected biocidal agents on gram-positive and gramnegative bacteria. J Appl Microbiol 2003;94:240-7. 
12. Vander Heijden R, Jacobs DI, Snoeijer W, Hallard D, Verpoorte R. The Catharanthus alkaloids: pharmacognosy and biotechnology. Curr Med Chem 2004;11:607-28.

13. Magnotta M, Murata J, Chen J, De Luca V. Identification of a low vindoline accumulating cultivar of Catharanthus roseus(L.) G. Don by alkaloid and enzymatic profiling. Phytochemistry 2006;31:1758-64.

14. Paikara D, Pandey B, Singh S. Phytochemical analysis and antimicrobial activity of Catharanthus roseus. Indian J Sci Res 2017;12:124-7.

15. Almagro L, Fernandez-Perez F, Pedreno MA. Indole alkaloids from Catharanthus roseus: bioproduction and their effect on human health. Molecules 2015;20:2973-3000.

16. Abdulkarim A, Sadiq Y. Evaluation of five medicinal plants used in diarrhea treatment in Nigeria. J Ethnopharmacol 2005;101: 27-30.

17. Appidi JR, Grierson DS Afolayan. The ethnobotanical study of plants used for the treatment of diarrhea treatment in the Eastern Cape South Africa. Pakistan J Bio Sci 2008;11:1961-3.

18. Prakash V, Timasheff SN. Mechanism of interaction of vinca alkaloids with tubulin: Catharanthine and vindoline. Biochem 1991;30:873-80.

19. Muhammad LR, Muhammad N, Tanveer A, Baqir SN Antimicrobial activity of different extracts of Catharanthus roseus. Clin Exp Med J 2009;3:81-5.

20. Chattopadhyay RR, Banerjee RN, Sarkar SK, Ganguly S, Basu TK Anti-inflammatory and acute toxicity studies with the leaves of Vinca rosea Linn in experimental animals. Ind J Physiol Pharmacol 1992;36:291-2.

21. K Rajbir, A Saroj. Alkaloids-important therapeutic secondary metabolites of plant origin. J Crit Rev 2015;2:1-8.

22. El-Sayed M, Verpoorte R. Methyl jasmonate accelerates catabolism of monoterpenoid indole alkaloids in Catharanthus roseus during leaf processing. Fitoterapia 2005;76:83-90.
23. Haines HH. The Botany of Bihar and Orissa. $2^{\text {nd }}$ ed. Gouranga press private Ltd; 1961.

24. Bergey DH, Whitman WB, Goodfellow, Kampfer P, Busse HJ Bergey's manual of systemic bacteriology. $2^{\text {nd }}$ ed. New York: Springer; 2012.

25. Heinzmann S, Entian KD, Stein T. Engineering bacillus subtilis ATCC6633 for improved production of the antibiotic subtilin. Appl Microbiol Biotechnol 2006;69:532-6.

26. Islam MA, Heuvelink AE, de Boer E, Sturm PD, Beumer RR, Zwietering $\mathrm{MH}$, et al. Shiga toxin producing Escherichia coli isolated from patients with diarrhea in Bangladesh. J Med Microbiol 2007;56:1-6.

27. Lowy FD. Staphylococcus aureus infections. N Engl J Med 1998;339:520-32.

28. Ferreres F, Pereira DM, Valentao P, Andrade PB, Seabra RM, Sottomayor M. New phenolic compounds and antioxidant potential of Catharanthus roseus. J Agric Food Chem 2008;56:9967-74.

29. Mustafa RN, Verpoorte R. Phenolic compounds in Catharanthus roseus. Phytochem Rev 2007;6:243-58.

30. Kumari K, Gupta S. Phytopotential of Catharanthus roseus L. (G.) Don var. "rosea" and "alba" against various pathogenic microbes in vitro. Int J Res Pure Appl Microbiol 2013;3:77-82.

31. Govindasamy, Srinivasan R. In vitro antibacterial activity and phytochemical analysis of Catharanthus roseus (Linn.) G. Don. Asian Pacific J Trop Biomed 2012;S155-S8.

32. Thongson C, Davidson PM, Mahakarnchanakul W, Weiss J. Antimicrobial activity of ultrasound-assisted solvent extracted spices. Lett Appl Microbiol 2004;39:401-6.

33. Almagro L, Gutierrez J, Pedreno MA, Sottomayor M. Synergistic and additive influence of cyclodextrins and methyl jasmonate on the expression of the terpenoid indole alkaloid pathway genes and metabolites in Catharanthus roseus cell cultures. Plant Cell Tissue Organ Cult 2014;119:543-51. 